\title{
Partitioning of the diffuse attenuation coefficient for photosynthetically available irradiance in a deep dendritic tropical lake
}

\author{
LUCIANA P.M. BRANDÃ ${ }^{1,2}$, LUDMILA S. BRIGHENTI ${ }^{2}$, PETER A. STAEHR', \\ FRANCISCO A.R. BARBOSA ${ }^{2}$ and JOSÉ F. BEZERRA-NETO ${ }^{2}$ \\ ${ }^{1}$ Department of Bioscience, Aarhus University, Frederiksborgvej, 399, DK-4000 Roskilde, Denmark \\ ${ }^{2}$ Limnea, Instituto de Ciências Biológicas, Universidade Federal de Minas Gerais, \\ Av. Antonio Carlos, 6627, 31270-901 Belo Horizonte, MG, Brazil
}

Manuscript received on January 11, 2016; accepted for publication on January 17, 2017

\begin{abstract}
We studied the effects of particulate and dissolved optically active components on the attenuation of photosynthetic active radiation (PAR) in a tropical lake. The temporal and spatial distribution of tripton, Chl- $a$ and $\mathrm{a}_{\mathrm{CDOM}}(440)$ and their relative contribution to the diffuse PAR attenuation coefficient $(K d)$ was investigated at 21 sites (dry and wet seasons and two intermediate periods) and at monthly interval at 1 pelagic site. Higher values of $K d$ were observed during the mixing period, characterized by a higher concentration of tripton and Chl- $a$ compared to the stratified rainy season. In the spatial sampling PAR attenuation was dominated by tripton absorption/scattering (average relative contribution of 79\%), followed by Chl- $a$ (average 11.6\%). In the monthly sampling tripton and Chl- $a$ accounted for most of the $K d$ with relative contributions of $47.8 \%$ and $35.6 \%$, respectively. Multiple linear regression analysis showed that Chl- $a$ and tripton in combination explained $97 \%$ of the monthly variation in $K d(\mathrm{p}<0.001)$, but Chl- $a$ had more influence (higher regression coefficient). Thus, although most of light attenuation was due to tripton, seasonal variations in phytoplankton abundance were responsible for most of the temporal fluctuations in $K d$.
\end{abstract}

Key words: CDOM, chlorophyll- $a, K d$ partition, light attenuation, tripton.

\section{INTRODUCTION}

Availability of photosynthetically active radiation (PAR; 400 to $700 \mathrm{~nm}$ ) in the water column provides the energy for primary producers and is a key determinant of the overall productivity of aquatic ecosystems (Parsons et al. 1984, Kirk 1994).

\footnotetext{
Correspondence to: Luciana Pena Mello Brandão

E-mail: lucianapmb@hotmail.com

* Contribution to the centenary of the Brazilian Academy of Sciences.
}

While it is well known that PAR is attenuated exponentially with depth, little is known of the causes for temporal and spatial variability in the vertical diffuse attenuation coefficient for downwelling PAR $\left(K d ; \mathrm{m}^{-1}\right)$ in tropical lakes.

Light attenuation in aquatic ecosystems is basically the sum of light absorbing and scattering optically active components present in water. These components are phytoplankton pigments (of which chlorophyll- $a$ dominates), colored dissolved 
organic matter (CDOM), pure water and tripton (defined in this type of studies as non pigmented particulate matter) (Kirk 1994, Pfannkuche 2002, Branco and Kremer 2005, Kelble et al. 2005).

Studies aiming to determine the relative contribution of optically active components to $K d$ have previously concentrated on shallow lakes (Somlyody and Koncsos 1991, Blom et al. 1994, James et al. 1997, Van Duin et al. 2001, Pierson et al.2003, Zhang et al. 2007a, b, Balogh et al. 2009), estuaries and coastal lagoons (Phlips et al. 1995, Christian and Sheng 2003, Lund-Hansen 2004, Kelble et al. 2005, Yamaguchi et al. 2013), while little information about partition of $K d$ is available on deep (Effler et al. 2010) and tropical lakes (Loiselle et al. 2008). The partition of this optical property is based on the equation:

$K d=K_{W}+K_{C D O M}+K_{\text {TRI }}+K_{\text {Chl-a }} \quad$ (Equation 1)

where $K_{W}$ is the partial attenuation coefficient by pure water, $K_{C D O M}$ by CDOM, $K_{T R I}$ by tripton and $K_{\text {Chl-a }}$ by Chl- $a$ (Kirk 1994, Phlips et al. 1995).

The concentrations of optically active components and how these attenuate light in the water column determine the amount of light available for photosynthesis. Therefore, the available light restricts production, abundance, and distribution of pelagic and benthic primary producers, with implications for higher trophic levels in the ecosystem (Parsons et al. 1984, McMahon et al. 1992, Gallegos and Moore 2000). Studies about $K d$ partition provide important understanding of how each component is responsible for the attenuation of light and this fact also allows predict the underwater light climate from the concentrations of these components (Zhang et al. 2007a).

Spatial variations in PAR light attenuation coefficients are expected in large and dendritic lakes because of the differences in depth and proximity to the border, which leads to less stability of the water column and increased input of allochthonous matter. The shallower regions of the lakes are susceptible to wind driven sediment resuspension which increases the concentration of suspended matter in the water column and reduces light penetration and thus primary production (Somlyody and Koncsos 1991). These variations also differ between seasons due to higher input via rainfall (rain period) and due to mixing of water column (dry period).

Lake Dom Helvécio (DH - Minas Gerais, Brazil) is a deep dendritic tropical lake located in a preserved area surrounded by Atlantic Forest. Although there is a greater input during rainy season, the water column stability in DH is large in this period (Brighenti et al. 2015) and the allochthonous matter coming with runoff from rains remains retained below the thermocline due to differences in water temperature (Reynolds 2009). Redistribution of particulate matter into the upper mixed layers accordingly occurs during the dryer and colder season which therefore is characterized by less transparent water. Following these observations, our hypotheses are that: 1) the total suspended matter - TSM (Chl- $a$ and tripton) present greater relative contribution in the attenuation of PAR radiation at all the sampling stations and seasons, as CDOM occurs at low concentrations in Lake DH and absorbs more in the range of ultraviolet spectrum; 2) the spatial variability in PAR attenuation coefficient values among the 21 sites can be explained by the influence of the lake shore in the closest sites (direct input of allochthonous organic matter and shalower water column compared to deeper sites); 3) the PAR attenuation coefficient is higher during the dryer mixing period due to elevated levels of suspended matter in the water column. In order to test these hypothesis, our objectives were to document the spatial and temporal contribution of tripton, Chl- $a$ and CDOM in total PAR attenuation through $K d$ partition study at Lake DH and determine how 
variations in optically attenuating conditions depend on the time and place of sampling.

\section{MATERIALS AND METHODS}

\section{STUDY SITE}

Dom Helvécio lake is located inside the Rio Doce State Park - PERD Southeast Brazil (S1946.94', W42 ${ }^{\circ} 35.48^{\prime}$ ). The lakes complex in the Middle Rio Doce is one of the most important districts of lakes in Brazil, with approximately 130 lakes, 42 of them located inside the PERD area, which is the largest remnant of the Atlantic Forest in Minas Gerais, totaling 36000 ha (Maia-Barbosa et al. 2010) (Fig. 1). This lake is one of the deepest natural lakes of Brazil (maximum depth: $39.5 \mathrm{~m}$ ), surrounded by Atlantic forest. It is oligotrophic (total phosphorus: 3.0-22.0 $\mu \mathrm{g} \mathrm{L}^{-1}$, annual mean $11.2 \mu \mathrm{g} \mathrm{L}^{-1}$; Chl- $a$ : 0.5-11.0 $\mu \mathrm{g} \mathrm{L}^{-1}$, annual mean $4.5 \mu \mathrm{g} \mathrm{L}^{-1}$ ), has a perimeter of $37.7 \mathrm{~km}$, area equal to $5.27 \times 10^{6} \mathrm{~m}^{2}$ and volume equal to $5.94 \times 10^{7} \mathrm{~m}^{3}$ (Bezerra-Neto and Pinto-Coelho 2008). Dom Helvécio is a warm monomictic lake, with thermal stratification period beginning in September and lasting until April (rainy period) and a mixed period from May to August (dry period) (Barbosa and Tundisi 1980).

\section{FIELD MEASUREMENTS}

The spatial sampling was carried out in January (Summer), April (transition-Autumn), August (Winter) and December (transition-Spring) 2013 at 21 sampling stations in the lake (Fig. 1c). Although in tropical environments the four seasons are not well defined and then are commonly separated into dry and rainy periods in aquatic studies, we included in this study the samplings during the transitions periods (autumn and spring) because they are important intermediate periods between the rainy and dry seasons. Temporal samples were taken monthly at a single station in the pelagic part of the lake (station 8, Fig. 1), from June 2011 to November 2012. Six data of temporal sampling and one of the spatial sampling stations (station 1 in January 2013) were not included in the analysis because the Chl- $a$ measurements were not analyzed in a timely manner and the values were of low accuracy.

Upon monthly sampling at the central deep region (station 8) of the lake, vertical profiles of water column temperature $\left({ }^{\circ} \mathrm{C}\right)$ were measured every meter from surface to $28 \mathrm{~m}$ using a Hydrolab DS5 probe. The surface irradiance $\left(\mathrm{E}_{0}\right)$ was obtained by a solar radiation sensor (WE300, Global Water ${ }^{\circledR}$ ) mounted just above lake surface on a buoy located at this station.

For spatial analysis, vertical profiles of photosynthetically active radiation (PAR) (between 10:00 and 14:00) were performed using a radiometer (BIC Biospherical Instruments). The profiles were made on the sun side of the boat avoiding shadows and measurements during days with great clouds were avoided. The radiometer was attached to a battery and notebook with the software LoggerLight TM (Biospherical Instruments) while collecting radiation data PAR and depth during descent and ascent up of the probe. In the spatial sampling the maximum depth of measurement of radiation was defined on the field when PAR reached $1 \mu$ Einsteins $\mathrm{m}^{2} \mathrm{~s}$. For monthly analysis, light profiles were measured at depths 0.1, 1.0, 2.0 and $3.0 \mathrm{~m}$ using a model UA-002 light sensors $\left(\mathrm{HOBO}^{\circledR}\right)$.

Water samples $(0.5 \mathrm{~m}$ from the surface) were collected using a van Dorn bottle (5L) and filtered immediately for Chl- $a(0.47 \mu \mathrm{m}$ Millipore filter $)$ and TSM (AP040 Millipore filter), and the filters were frozen until analysis. Water samples were also filtered for analysis of dissolved organic carbon (DOC) and colored dissolved organic matter (CDOM) $(0.22 \mu \mathrm{m}$ Millipore filter) and stored in amber glass bottles (pre-washed with distilled water and hydrochloric acid $10 \%$ ) at $4{ }^{\circ} \mathrm{C}$ in the dark. 

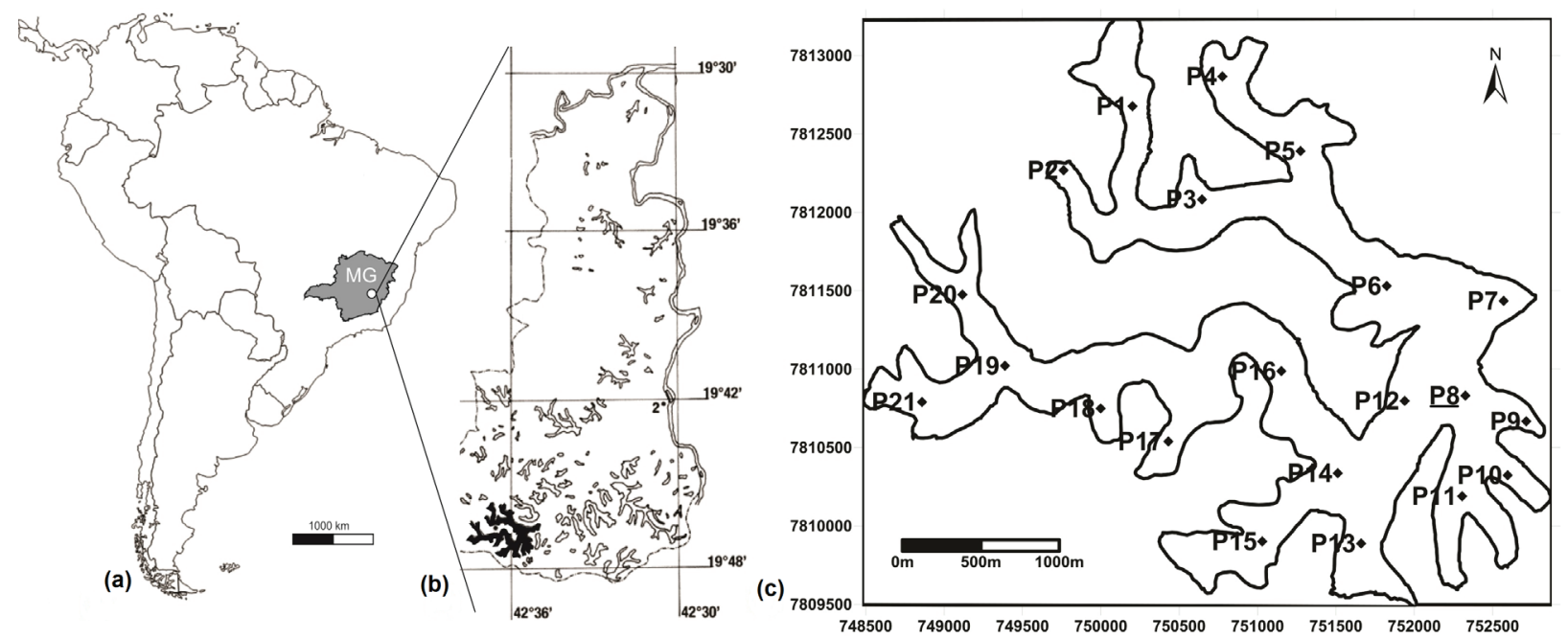

Figure 1 - Location of Dom Helvécio lake in Minas Gerais (a), inside of the Rio Doce State Park (b), Middle Rio Doce and the spatial sampling stations (P1-P21) (c). The station P8 (c; underlined) also represents the location of monthly sampling. The numbers on the axes correspond to geographic coordinates.

\section{LABORATORY ANALYSIS AND CALCULATION OF THE OPTICAL PROPERTIES}

The diffuse PAR attenuation coefficient $(K d)$ was calculated as the linear slope between depth and the natural logarithm of the measured downwelling PAR radiation. From $K d$ we calculated the depth of the euphotic zone $\left(\mathrm{Z}_{\mathrm{eu}}=4.6 / \mathrm{Kd} ; \mathrm{m}\right)$ where $1 \%$ of the radiation incident on the surface is reached (Kirk 1994).

The measurement of concentration of Chl- $a$ was obtained by acetone extraction (90\%) measured in a spectrophotometer (UV-VIS Shimadzu) at 665 and $750 \mathrm{~nm}$ and calculated according to APHA (1998). Total suspended matter (TSM; $\mathrm{mg} \mathrm{L}^{-1}$ ) were determined by the gravimetric method, considering the difference between the dry weight of AP40 Millipore filters $\left(105^{\circ} \mathrm{C}\right.$ for 2 hours) before and after the filtration of water samples (APHA 1998). The tripton represents the non-living fraction of the suspension material, but in this study it represents the non-pigmented part of TSM (non-phytoplankton particulate matter). This was obtained subtracting the dry weight of the phytoplankton from the TSM. The ratio between concentration of Chl- $a$ corrected by pheophytin and the dry weight of phytoplankton was assumed 1:100 (Phlips et al. 1995). Thus, the concentration of the Chl- $a$ corrected by pheophytin (mg L- ${ }^{1}$ ) was multiplied by 100 to obtain the dry weight of phytoplankton and then subtracted from TSM (mg L-1) to obtain the concentration of tripton (mg L- ${ }^{1}$ ) (Christian and Sheng 2003).

The DOC concentration $\left(\mathrm{mg} \mathrm{L}^{-1}\right)$ was obtained by catalytic oxidation method of high temperature using TOC Analyzer (Shimadzu TOC - 5000).

The spectral absorption of CDOM was measured at $440 \mathrm{~nm}\left(\mathrm{a}_{\mathrm{CDOM}}(440)\right)$ in a spectrophotometer (UV-VIS Shimadzu) using $5 \mathrm{~cm}$ quartz cuvette and Milli-Q water as a reference. The absorption spectra of each sample was performed in triplicate and determined using the Spectrum Pack Program software (Shimadzu Inc.). The absorption coefficients were derived from the absorption spectra (A) at $440 \mathrm{~nm}\left(\mathrm{~m}^{-1}\right)$ according to the equation 2 (Kirk 1994):

$a_{\text {CDOM }}(440)=2.303 A(440) l^{-1}$

(equation 2)

Where $l$ is the optical path of the cuvette (in meters). Absorption coefficients were corrected for backscattering by subtracting the value of the coefficient at $700 \mathrm{~nm}$ from the absorbance at 440 
$\mathrm{nm}$. The spectrophotometric absorption coefficient at $440 \mathrm{~nm}$ was used as an index of CDOM concentration (Williamson et al. 1996).

We used the software Lake Analyzer (Read et al. 2011) to determine the depth of the upper mixed layer $\left(\mathrm{Z}_{\text {mix }}\right)$ and the water column stability (Schmidt Stability-St) from monthly temperature profiles. Mean available light in the upper mixed layer $\left(\mathrm{E}_{\text {mean }}\right.$; mol photons $\mathrm{m}^{-2} \mathrm{~d}^{-1}$ ) was estimated from surface light, light attenuation and mixing depth as described in Staehr and Sand-Jensen (2007). Accumulated rainfall recorded at every three hours was obtained from a meteorological station located less than $2 \mathrm{~km}$ from the lake (http://sinda.crn2.inpe. $\mathrm{br} / \mathrm{PCD} /$ ).

Unfiltered water samples were taken for analysis of total nitrogen (TOC Analyzer, Shimadzu TOC -5000 ) and total phosphorus (according to Mackereth et al. 1978).

\section{PARTITIONING OF THE DIFUSE PAR ATTENUATION COEFFICIENT}

The partition of $K d$ was performed for the spatial (integrating the spatial data from four seasons sampling in 2013) and temporal data (monthly sampling at site 8 in 2011 and 2012) separately, but using the same equations.

The attenuation of the PAR radiation can be partitioned according to the following equation 3 (Yamaguchi et al. 2013):

$K d=K_{W}+K_{C D O M}+K_{T S M}$

(equation 3)

where $K_{W}, K_{C D O M}$ and $K_{T S M}$ are the partial attenuation coefficient due to respectively pure water, $\mathrm{a}_{\text {СDOM }}(440)$ and TSM in the PAR range (400 to 700 $\mathrm{nm})$.

The light attenuation by the pure water $\left(K_{W}\right)$ was assumed to be constant at $0.027 \mathrm{~m}^{-1}$ (Smith and Baker 1978). The PAR attenuation by CDOM $\left(K_{C D O M}\right)$ was estimated according to the equation 4
(Pfannkuche 2002, Lund-Hansen 2004, Zhang et al. 2007a):

$K_{C D O M}=0.221 * a_{C D O M}(440)$

(equation 4)

Where, $a_{C D O M}(440)$ is the value of the absorption coefficient measured at $440 \mathrm{~nm}$ and 0.221 is the specific absorption coefficient of CDOM at 440 $\mathrm{nm}$.

The light attenuation of TSM can be subdivided according to the equation 5 :

$K_{T S M}=K_{C h l-a}+K_{T R I}$

(equation 5)

Where $K_{C h l-a}$ and $K_{T R I}$ are the partial attenuation coefficients of phytoplankton (as measured by Chl-a) and tripton, respectively. To calculate the $K_{T S M}$ we subtracted the sum $\left(K_{W}+K_{C D O M}\right)$ from $K d$ (Yamaguchi et al. 2013).

A simple linear regression analysis was performed between the $K_{T S M}\left(\mathrm{~m}^{-1}\right)$ and the Chl- $a$ concentration $\left(\mu \mathrm{g} \mathrm{L}^{-1}\right)$ to estimate the specific attenuation coefficient of the Chl- $a$, according to equation 6 (Yamaguchi et al. 2013):

$K_{T S M}=b *[C h l-a]+c$

(equation 6)

Where the slope $b$ is the specific attenuation coefficient of Chl- $a\left(K_{C h l-a}^{*}\right)$ and $c$ is the intercept. The Chl- $a$ absorption coefficient $\left(K_{C h l-a} ; \mathrm{m}^{-1}\right)$ was obtained by multiplying $K_{\text {Chl-a }}^{*}$ with [Chl- $\left.a\right]$. The $K_{T R I}$ (light absorption by non-pigmented particulate matter) was finally obtained according to equation 5 by subtracting $K_{\text {Chl-a }}$ from $K_{T S M}$ (Yamaguchi et al. 2013).

Following the model in equation 1 is possible to calculate the relative contributions (\%) of each component in the total $K d(100 \%)$.

\section{STATISTICAL ANALYSIS}

Kruskal-Wallis (One Way Analysis of Variance) and pair wise test (Tukey Test) were performed to assess seasonal differences in $K d$ values. Simple 
and multiple linear regressions were made between concentrations of optically active components and partial and total coefficients of PAR attenuation. To demonstrate the spatial distribution of $K d$ and the optical components maps were made using a Kriging interpolation technique with Surfer 10 software.

\section{RESULTS}

\section{OVERALL PATTERNS IN LAKE PHYSICS AND WATER CHEMISTRY}

Periods with full mixing occurred between June and August in all three years. The water surface temperature ranged from 21 to $31^{\circ} \mathrm{C}$ with lowest temperatures during the mixing period. The photic zone $\left(Z_{\text {eu }}\right)$ ranged from 3.9 to $14.3 \mathrm{~m}$, reaching greater depths during the stratified rainy periods. Greater stability of the water column (Schmidt) was accordingly observed in the rainy season (mean Schmidt stability $=386.4 \mathrm{~J} \mathrm{~m}^{-2}$ ). The deep water temperature remained lower than the surface temperature during the entire rain period and was stable throughout the year (annual average $23.5^{\circ} \mathrm{C}$ $\pm 1^{\circ} \mathrm{C}$ standard deviation). The depth of the mixing layer was greater in dry and colder period reached a maximum of $27.9 \mathrm{~m}$, while during the warmer rainy season $Z_{\text {mix }}$ reached a maximum of $13.4 \mathrm{~m}$ (Table I and Fig. 2).

DOC occurred in higher concentrations during the onset of the rains (December, spatial average $6.5 \mathrm{mg} \mathrm{L}^{-1}$ ) and mixing in winter (spatial average 6.5 and monthly average $5.9 \mathrm{mg} \mathrm{L}^{-1}$ ). The DOC concentration in the deeper hypolimnetic waters was higher during thermal stratification (4.9 in November and $5.1 \mathrm{mg} \mathrm{L}^{-1}$ in December 2012) than in the upper mixed surface waters $\left(2.1 \mathrm{mg} \mathrm{L}^{-1}\right.$ in November and $1.5 \mathrm{mg} \mathrm{L}^{-1}$ in December 2012) and elevated DOC levels were accordingly stored in the hypolimnion until the onset of mixing in June. Total nitrogen (TN) occurred in higher concentrations during the mixed dry period (spatial average 357.6 and monthly average $446.6 \mu \mathrm{g} \mathrm{L}^{-1}$ ) compared to conditions in the upper mixed layer during stratification (averages between 276.8 and $351.7 \mu \mathrm{g} \mathrm{L}^{-1}$ ). The total phosphorus (TP) occurred in higher concentrations during winter, but only for the spatial sampling (average $12.8 \mu \mathrm{g} \mathrm{L}^{-1}$ ), and no difference was observed between dry and rainy in the monthly sample (Table I and Fig. 2a-h).

\section{SPATIAL VARIATIONS IN OPTICAL PROPERTIES}

The coefficients of variation were used to estimate the variability of $K d$ and optically active components at each site. The spatial distribution of these coefficients of variation and mean values for each parameter in the four sampling periods are shown in Figs. 3 and 4. The largest variation observed for $K d$ occurred at sites $7(\mathrm{CV}=0.38), 11$ $(\mathrm{CV}=0.43)$ and $15(\mathrm{CV}=0.35)$, while the lowest ocurred at sites $3(\mathrm{CV}=0.10), 18(\mathrm{CV}=0.14)$ and $21(\mathrm{CV}=0.13)$. Chl- $a$ presented coefficients of variation between 0.20 (site 12) and 0.83 (site 9), tripton presented between 0.08 (site 6) and 0.80 (site 1) and TSM ranged from 0.05 (site 7) to 0.56 (site 21). The highest variation occurred to $\mathrm{a}_{\text {CDOM }}(440)$ ranging from 0.17 (site 21 ) to 2.00 (sites 5 and 7). There was no significant correlation $(p>0.05)$ among the coefficients of variation of all parameters measured or between the coefficients and the depth of the sites or proximity to shore.

The spatial variation of the $K d$ was also different for each sampling period, ranging from 15 to $18 \%$ (measured by the coefficient of variation - $\mathrm{CV}=$ standard deviation / average) among sites in the spring (December $-\mathrm{CV}=0.15$ ) and summer (January - $\mathrm{CV}=0.18$ ), and less than $8 \%$ in autumn and winter (April - $\mathrm{CV}=0.08$; August - $\mathrm{CV}=0.06$ ). The spatial variation for Chl- $a$ was higher in summer (56\%) and less than $30 \%$ in other sampling periods (April - $\mathrm{CV}=0.26$; August - $\mathrm{CV}=0.30$; December $-\mathrm{CV}=0.29)$, while the variation of tripton was higher in winter $(45 \%)$ and close at other periods (January - CV $=0.36$; April - CV $=0.31$; December 
TABLE I

Summary of parameters measured during temporal and spatial analyzes in the lake between 2011 and 2013.

\begin{tabular}{|c|c|c|c|c|c|c|c|}
\hline & & \multicolumn{4}{|c|}{ Spatial sampling } & \multicolumn{2}{|c|}{ Temporal sampling } \\
\hline & & $\begin{array}{c}\text { Summer } \\
(\text { Jan. 2013) }\end{array}$ & $\begin{array}{c}\text { Autumn } \\
\text { (Apr. 2013) }\end{array}$ & $\begin{array}{c}\text { Winter } \\
\text { (Aug. 2013) }\end{array}$ & $\begin{array}{c}\text { Spring } \\
\text { (Dec. 2013) }\end{array}$ & Dry season & Rainy season \\
\hline \multirow{3}{*}{$K d_{(\mathrm{PAR})}\left(\mathrm{m}^{-1}\right)$} & Mean & 0.46 & 0.64 & 0.78 & 0.52 & 0.91 & 0.66 \\
\hline & Min-Max & $0.32-0.59$ & $0.51-0.74$ & $0.68-0.91$ & $0.41-0.68$ & $0.66-1.33$ & $0.37-1.26$ \\
\hline & std dev & 0.08 & 0.05 & 0.05 & 0.08 & 0.26 & 0.26 \\
\hline \multirow{3}{*}{ Tripton $\left(\mathrm{mg} \mathrm{L}^{-1}\right)$} & Mean & 1.03 & 1.09 & 1.19 & 1.14 & 1.65 & 1.33 \\
\hline & Min-Max & $0.18-1.65$ & $0.68-1.80$ & $0.09-2.37$ & $0.57-2.19$ & $0.46-3.03$ & $0.40-1.88$ \\
\hline & std dev & 0.37 & 0.34 & 0.53 & 0.34 & 0.99 & 0.57 \\
\hline \multirow{3}{*}{ Chl- $a\left(\mu \mathrm{g} \mathrm{L}^{-1}\right)$} & Mean & 3.31 & 6.98 & 4.81 & 2.94 & 6.15 & 3.28 \\
\hline & Min-Max & $0.47-6.90$ & $2.68-10.91$ & $2.10-7.22$ & $1.13-4.80$ & $1.69-8.91$ & $0.59-6.11$ \\
\hline & std dev & 1.86 & 1.82 & 1.47 & 0.87 & 3.20 & 2.20 \\
\hline \multirow{3}{*}{$\mathrm{a}_{\mathrm{CDOM}}(440)\left(\mathrm{m}^{-1}\right)$} & Mean & 0.16 & 0.10 & 0.11 & 0.12 & 0.36 & 0.28 \\
\hline & Min-Max & $0.00-0.30$ & $0.00-0.30$ & $0.00-0.40$ & $0.00-0.40$ & $0.10-0.60$ & $0.10-0.40$ \\
\hline & std dev & 0.10 & 0.08 & 0.10 & 0.11 & 0.19 & 0.11 \\
\hline \multirow{3}{*}{$\mathrm{TSM}\left(\mathrm{mg} \mathrm{L}^{-1}\right)$} & Mean & 1.36 & 1.79 & 1.67 & 1.43 & 2.26 & 1.66 \\
\hline & Min-Max & $0.36-2.13$ & $1.28-2.28$ & $0.57-2.77$ & $0.91-2.40$ & $1.29-3.20$ & $0.90-2.42$ \\
\hline & std dev & 0.39 & 0.24 & 0.55 & 0.35 & 0.73 & 0.54 \\
\hline \multirow{3}{*}{$\mathrm{DOC}\left(\mathrm{mg} \mathrm{L}^{-1}\right)$} & Mean & 4.30 & 3.09 & 6.46 & 6.47 & 5.87 & 5.24 \\
\hline & Min-Max & $3.31-5.05$ & $2.49-3.46$ & $5.25-8.32$ & $4.10-8.47$ & $2.38-11.21$ & $1.92-8.73$ \\
\hline & std dev & 0.44 & 0.29 & 0.98 & 0.89 & 3.08 & 2.04 \\
\hline \multirow{3}{*}{ Mixing layer (m) } & Mean & - & - & - & - & 17.73 & 7.25 \\
\hline & Min-Max & - & - & - & - & $8.40-27.90$ & $5.00-13.40$ \\
\hline & std dev & - & - & - & - & 7.61 & 2.16 \\
\hline \multirow{3}{*}{$\begin{array}{l}\text { Euphotic zone } \\
\text { (m) }\end{array}$} & Mean & 10.37 & 7.22 & 5.94 & 9.08 & 5.65 & 8.22 \\
\hline & Min-Max & $7.80-14.30$ & $6.20-8.90$ & $5.00-6.70$ & $6.80-11.30$ & $3.90-7.00$ & $4.10-12.50$ \\
\hline & std dev & 1.91 & 0.62 & 0.36 & 1.31 & 1.12 & 2.55 \\
\hline \multirow{3}{*}{$\begin{array}{l}\text { Surface } \\
\text { Temperature }\left({ }^{\circ} \mathrm{C}\right)\end{array}$} & Mean & 30.00 & 28.73 & 25.40 & 31.00 & 24.27 & 27.41 \\
\hline & Min-Max & - & - & - & - & $20.90-25.70$ & $24.50-31.40$ \\
\hline & std dev & - & - & - & - & 1.58 & 1.89 \\
\hline \multirow{3}{*}{$\begin{array}{l}\text { Water column } \\
\text { depth }(\mathrm{m})\end{array}$} & Mean & 14.03 & - & 13.04 & - & 28.50 & 28.50 \\
\hline & Min-Max & $4.50-30.00$ & - & $2.90-30.00$ & - & $27.00-30.00$ & $27.00-30.00$ \\
\hline & std dev & 8.52 & - & 8.58 & - & 0.84 & 0.84 \\
\hline \multirow{3}{*}{$\begin{array}{l}\text { Total nitrogen } \\
\left(\mu \mathrm{g} \mathrm{L}^{-1}\right)\end{array}$} & Mean & 276.81 & 278.53 & 357.60 & 125.14 & 446.61 & 351.71 \\
\hline & Min-Max & $\begin{array}{l}215.49- \\
424.10\end{array}$ & $\begin{array}{l}242.62- \\
342.10\end{array}$ & $12.73-519.71$ & $3.68-431.47$ & $292.21-688.20$ & $229.27-695.29$ \\
\hline & std dev & $\begin{array}{l}424.10 \\
41.03\end{array}$ & $\begin{array}{l}342.10 \\
27.05\end{array}$ & 146.42 & 158.91 & 127.29 & 128.15 \\
\hline \multirow{3}{*}{$\begin{array}{l}\text { Total phosphorus } \\
\left(\mu \mathrm{g} \mathrm{L}^{-1}\right)\end{array}$} & Mean & 3.78 & - & 12.75 & 8.27 & 8.06 & 8.22 \\
\hline & Min-Max & $2.90-5.61$ & - & $5.69-21.77$ & $4.80-11.90$ & $5.46-10.74$ & $4.60-12.82$ \\
\hline & std dev & 0.97 & - & 4.10 & 1.83 & 2.09 & 2.42 \\
\hline \multirow{3}{*}{$\begin{array}{l}\text { Schmidt stability } \\
\left(\mathrm{J} \mathrm{m}^{2}\right)\end{array}$} & Mean & - & - & - & - & 124.16 & 386.43 \\
\hline & Min-Max & - & - & - & - & $31.90-282.90$ & $142.30-621.90$ \\
\hline & std dev & - & - & - & - & 82.72 & 167.89 \\
\hline
\end{tabular}

$-\mathrm{CV}=0.30) . \mathrm{a}_{\mathrm{CDOM}}(440)$ presented larger variation than other optically active components with a minimum of $64 \%$ in summer and between 85 and $89 \%$ at other periods (April - $\mathrm{CV}=0.85$; August $\mathrm{CV}=0.89$; December $-\mathrm{CV}=0.88)$.
We found a significant variation in $K d$ between sampling seasons (Kruskal-Wallis One Way Analysis of Variance, $\mathrm{p}<0.001)$, except between January (summer) and December 2013 (Tukey Test, $\mathrm{p}>0.05$ ). The $K d$ ranged from $0.32 \mathrm{~m}^{-1}$ (station P11 

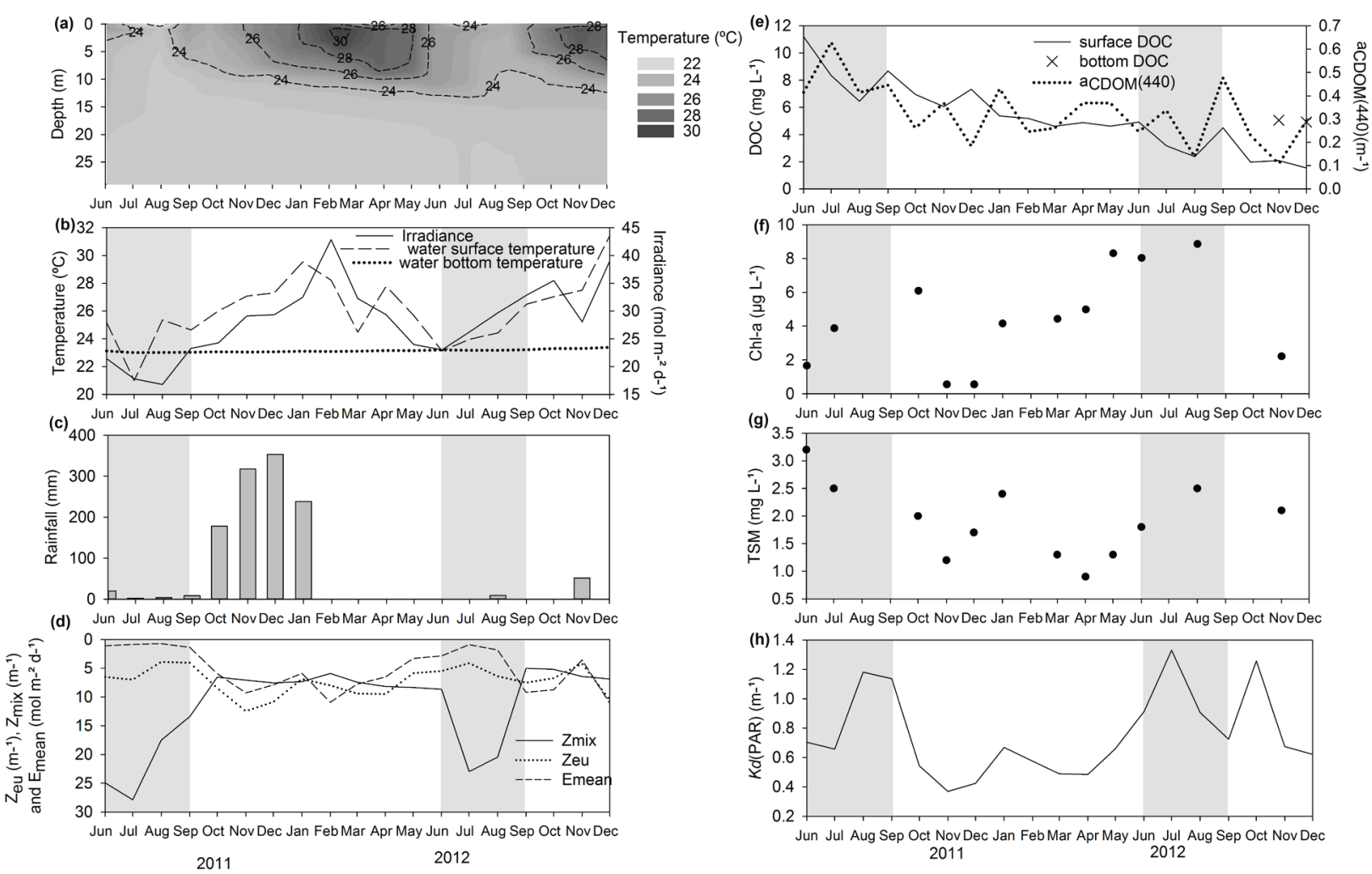

Figure 2 - Monthly variation of the (a) water temperature depth profile, (b) surface irradiance, (c) rainfall, (d) mixing layer depth $\left(Z_{\text {mix }}\right)$, euphotic zone depth $\left(Z_{e u}\right)$, mean light climate $\left(E_{\text {mean }}\right)$, (e) dissolved organic carbon, colored dissolved organic matter, (f) chlorophyll- $a,(\mathbf{g})$ total suspended matter and (h) PAR attenuation coefficient $(K d(P A R))$ from June 2011 to December 2012.

during the summer) to $0.91 \mathrm{~m}^{-1}$ (station P11 during the winter) during the entire period (average 0.60 $\mathrm{m}^{-1}$ ). Higher values of $K d$ (average $0.78 \mathrm{~m}^{-1}$ ) were observed during the dry winter period, characterized by a fully mixed water column, while lower values (average $0.46 \mathrm{~m}^{-1}$ ) were observed during the warm, thermally stratified rainy season (January and December) (Table I and Fig. 3). The coefficients of determination $\left(R^{2}\right)$ for the calculation of $K d$ from light vs depth were always higher than 0.9 which indicates a vertically homogeneous water column in relation to the optically active components (Zhang et al. 2007a), even during the stratified period.

The Chl- $a$ concentrations varied 20 fold between 0.5 (station P15 in the summer) and 11.0 $\mu \mathrm{g} \mathrm{L}^{-1}$ (station 8 in the intermediate period in April) (average $4.5 \mu \mathrm{g} \mathrm{L}^{-1}$ ). In comparison the TSM concentrations varied 8 fold and ranged from 0.4 (station P21 in the summer) to $2.8 \mathrm{mg} . \mathrm{L}^{-1}$ (station P21 in winter) (average $1.6 \mathrm{mg} \mathrm{L}^{-1}$ ). Higher Chl- $a$ and TSM concentrations were observed in April and winter. The tripton concentration ranged from 0.1 (station P8 in the winter) to $2.4 \mathrm{mg} \mathrm{L}^{-1}$ (station P21 in winter) (average $1.1 \mathrm{mg} \mathrm{L}^{-1}$ ). Although tripton concentrations reached similar levels as TSM, the spatial variation in tripton was much higher (26 fold), with the highest tripton concentrations also observed during winter where water column was fully mixed. The $\mathrm{a}_{\mathrm{CDOM}}(440)$ varied from 0 to $0.4 \mathrm{~m}^{-1}$, average $0.1 \mathrm{~m}^{-1}$. Higher $\mathrm{a}_{\mathrm{CDOM}}(440)$ concentrations were observed in the summer rainy period (Table I).

Using the additive model (equation 1) tripton was found to contribute most to the attenuation of visible light all year round and at all sampling 

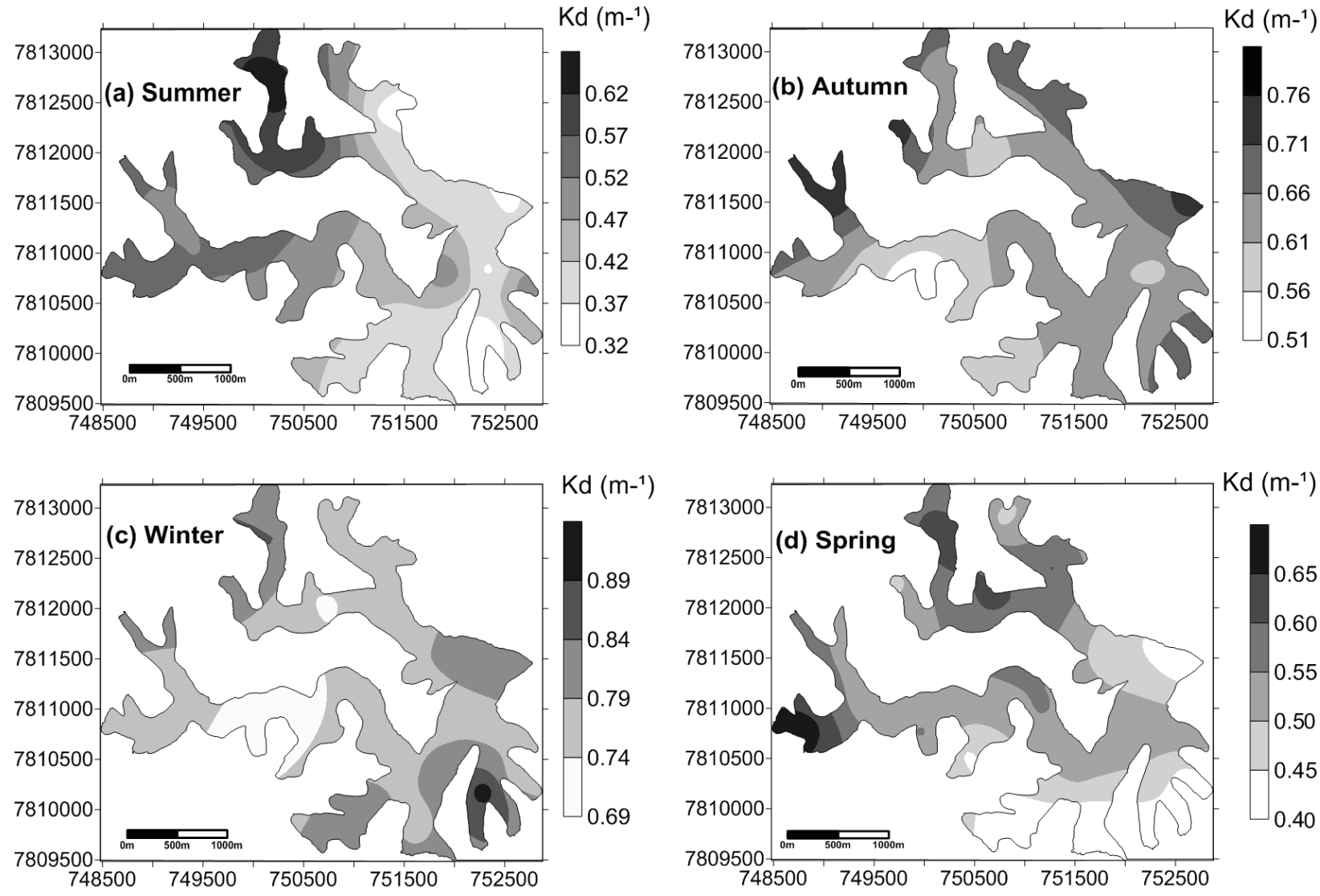

Figure 3 - Spatial variation of the attenuation coefficient of photosynthetically active radiation $\left(\mathrm{m}^{-1}\right)$ in the summer (January 2013 - a), autumn (April 2013 - b), winter (August 2013 - c) and spring (December 2013 - d). Notice that the scales are not similar. The numbers on the axes correspond to geographic coordinates.

stations during spatial sampling (minimum 50\%, maximum $91 \%$ and average $79 \%$ ). The relative contribution of phytoplankton pigments estimated from Chl- $a$ showed a minimum of $2 \%$, maximum $30.2 \%$ and average $11.6 \%$ for both seasonal and spatial variations. The $\mathrm{a}_{\mathrm{CDOM}}(440)$ varied from a minimum contribution of $0 \%$ to a maximum of $15.6 \%$, and average of $4.8 \%$. The pure water contribution ranged between $2.9 \%$ and $8.4 \%$, with an average of $4.7 \%$ (Fig. 5). With increasing tripton concentration and its relative contribution to light attenuation, $K d$ also increased. In comparison the contributions of Chl- $a$ and $\mathrm{a}_{\mathrm{CDOM}}(440)$ to PAR attenuation were lower and tended to decrease with higher $K d$ values (Fig. 6). Since the absorption of pure water is constant its relative contribution to $K d$ decreased with increasing attenuation by the other optical components. The specific attenuation coefficients for each optically active component are shown in Table II.

Considering the four sampling events as replicates we did not observe significant relations among the spatial distribution of the concentration of optically active components - Pearson's correlations between Chl- $a$ and tripton $(\mathrm{R}=-0.22$, $\mathrm{p}$ $=0.33)$; Chl $-a$ and $\mathrm{a}_{\mathrm{CDOM}}(440)(\mathrm{R}=-0.10, \mathrm{p}=0.65)$; tripton and $\mathrm{a}_{\mathrm{CDOM}}(440)(\mathrm{R}=-0.16, \mathrm{p}=0.47)$ (Fig. $6)$. The spatial distribution of $K d$ was significantly correlated only with Chl- $a(\mathrm{R}=0.31, \mathrm{p}<0.01)$ and we did not observe significant correlations between $K d$ and tripton $(\mathrm{R}=0.13, \mathrm{p}=0.24)$ or $\mathrm{a}_{\mathrm{CDOM}}(440)$ $(\mathrm{R}=-0.04 .22, \mathrm{p}=0.67)$. 
TABLE II

Specific attenuation coefficients of Chl- $a$, tripton, CDOM and water and their contribution to PAR attenuation during monthly and spatial sampling.

\begin{tabular}{|c|c|c|c|c|c|c|c|c|c|c|c|}
\hline \multirow[b]{2}{*}{ Monthly sampling } & & \multirow[b]{2}{*}{$K d(P A R)$} & \multicolumn{5}{|c|}{ Specific attenuation coefficients $\left(\mathrm{m}^{-1}\right)$} & \multicolumn{4}{|c|}{$\begin{array}{c}\text { Contribution to PAR } \\
\text { attenuation }(\%)\end{array}$} \\
\hline & & & $\mathbf{K}_{\text {Chl- } a}$ & $\mathbf{K}_{\mathrm{TRI}}$ & $\mathbf{K}_{\text {СDOM }}$ & $\mathbf{K}_{\mathbf{w}}$ & $\mathbf{K}_{\mathrm{TSM}}$ & $\mathbf{K}_{\text {Chl- } a}$ & $K_{\text {TRI }}$ & $\mathbf{K}_{\text {СDOM }}$ & $\mathbf{K}_{\mathbf{w}}$ \\
\hline June-11 & & 0.70 & 0.09 & 0.50 & 0.09 & 0.03 & 0.58 & 12 & 71 & 13 & 4 \\
\hline July-11 & & 0.66 & 0.20 & 0.29 & 0.14 & 0.03 & 0.49 & 31 & 44 & 21 & 4 \\
\hline October-11 & & 0.54 & 0.32 & 0.14 & 0.06 & 0.03 & 0.46 & 58 & 26 & 11 & 5 \\
\hline November-11 & & 0.37 & 0.03 & 0.23 & 0.08 & 0.03 & 0.26 & 8 & 63 & 22 & 7 \\
\hline December-11 & & 0.42 & 0.03 & 0.33 & 0.04 & 0.03 & 0.36 & 7 & 77 & 10 & 6 \\
\hline January-12 & & 0.67 & 0.22 & 0.33 & 0.10 & 0.03 & 0.55 & 32 & 50 & 14 & 4 \\
\hline March-12 & & 0.49 & 0.23 & 0.17 & 0.06 & 0.03 & 0.40 & 47 & 36 & 12 & 6 \\
\hline April-12 & & 0.48 & 0.26 & 0.12 & 0.08 & 0.03 & 0.38 & 53 & 24 & 17 & 6 \\
\hline May-12 & & 0.66 & 0.43 & 0.12 & 0.08 & 0.03 & 0.55 & 65 & 18 & 12 & 4 \\
\hline June-12 & & 0.91 & 0.42 & 0.42 & 0.05 & 0.03 & 0.83 & 46 & 45 & 6 & 3 \\
\hline August-12 & & 0.91 & 0.46 & 0.39 & 0.03 & 0.03 & 0.85 & 51 & 43 & 3 & 3 \\
\hline November-12 & & 0.67 & 0.11 & 0.51 & 0.02 & 0.03 & 0.62 & 17 & 75 & 4 & 4 \\
\hline Spatial sampling & & $K d(P A R)$ & $\mathbf{K}_{\text {Chl- } a}$ & $\mathbf{K}_{\mathrm{TRI}}$ & $\mathbf{K}_{\text {CDOM }}$ & $\mathbf{K}_{\mathbf{w}}$ & $\mathbf{K}_{\text {TSM }}$ & $\mathbf{K}_{\text {Chl-a }}$ & $\mathbf{K}_{\mathrm{TRI}}$ & $\mathbf{K}_{\text {СDOM }}$ & $\mathbf{K}_{\mathrm{w}}$ \\
\hline \multirow[t]{4}{*}{ January-2013 } & Mean & 0.46 & 0.05 & 0.35 & 0.04 & 0.03 & 0.40 & 12 & 74 & 8 & 6 \\
\hline & $\min$ & 0.32 & 0.01 & 0.16 & 0.00 & 0.03 & 0.26 & 2 & 50 & 0 & 5 \\
\hline & $\max$ & 0.59 & 0.10 & 0.54 & 0.07 & 0.03 & 0.57 & 30 & 91 & 14 & 8 \\
\hline & SD & 0.08 & 0.03 & 0.10 & 0.02 & 0.00 & 0.08 & 8 & 11 & 5 & 1 \\
\hline \multirow[t]{4}{*}{ April-2013 } & Mean & 0.64 & 0.11 & 0.49 & 0.02 & 0.03 & 0.59 & 17 & 76 & 3 & 4 \\
\hline & $\min$ & 0.51 & 0.04 & 0.35 & 0.00 & 0.03 & 0.46 & 5 & 68 & 0 & 4 \\
\hline & $\max$ & 0.74 & 0.17 & 0.65 & 0.06 & 0.03 & 0.71 & 28 & 88 & 9 & 5 \\
\hline & SD & 0.05 & 0.03 & 0.07 & 0.02 & 0.00 & 0.06 & 4 & 5 & 3 & 0 \\
\hline \multirow[t]{4}{*}{ August-2013 } & Mean & 0.78 & 0.07 & 0.65 & 0.03 & 0.03 & 0.72 & 9 & 84 & 3 & 3 \\
\hline & $\min$ & 0.68 & 0.03 & 0.53 & 0.00 & 0.03 & 0.62 & 4 & 76 & 0 & 3 \\
\hline & $\max$ & 0.91 & 0.11 & 0.76 & 0.08 & 0.03 & 0.81 & 15 & 91 & 9 & 4 \\
\hline & SD & 0.05 & 0.02 & 0.06 & 0.02 & 0.00 & 0.05 & 3 & 4 & 3 & 0 \\
\hline \multirow[t]{4}{*}{ December-2013 } & Mean & 0.52 & 0.04 & 0.42 & 0.03 & 0.03 & 0.46 & 9 & 81 & 5 & 5 \\
\hline & $\min$ & 0.41 & 0.02 & 0.31 & 0.00 & 0.03 & 0.35 & 3 & 71 & 0 & 4 \\
\hline & $\max$ & 0.68 & 0.07 & 0.56 & 0.10 & 0.03 & 0.59 & 15 & 90 & 16 & 7 \\
\hline & SD & 0.08 & 0.01 & 0.07 & 0.02 & 0.00 & 0.07 & 3 & 5 & 4 & 1 \\
\hline
\end{tabular}

\section{MONTHLY TRENDS IN OPTICAL PROPERTIES}

From our monthly sampling we found that $K d$ ranged from a minimum of $0.4 \mathrm{~m}^{-1}$ (November 2011) to a maximum of $1.3 \mathrm{~m}^{-1}$ (July 2012) around an average of $0.8 \mathrm{~m}^{-1}$. Highest values were as previously described observed in the dry period with full mixing of the water column (average 0.9 $\mathrm{m}^{-1}$ ), while in the warm stratified rain period had a lower average of $0.7 \mathrm{~m}^{-1}$ (Table I and Fig. 2-h).
The Chl- $a$ concentrations ranged 16 fold ( $\mathrm{min}$ December 0.6; max August $8.9 \mu \mathrm{gL}^{-1}$ ) with an average of $4.5 \mu \mathrm{gL}^{-1}$. Higher TSM concentrations occurred during dry periods and the concentrations ranged only 3.5 fold from 0.9 (April 2012) to 3.2 (June 2011) (average of $1.9 \mathrm{mg} \mathrm{L}^{-1}$ ). Higher tripton concentrations were observed in dry periods (June and July 2011 and August 2012) and in two months of rain period (January and November 2012), and ranged 8 fold (average $1.5 \mathrm{mg} \mathrm{L}^{-1}$ ). The $\mathrm{a}_{\mathrm{CDOM}}(440)$ absorption ranged from 0.1 (November 

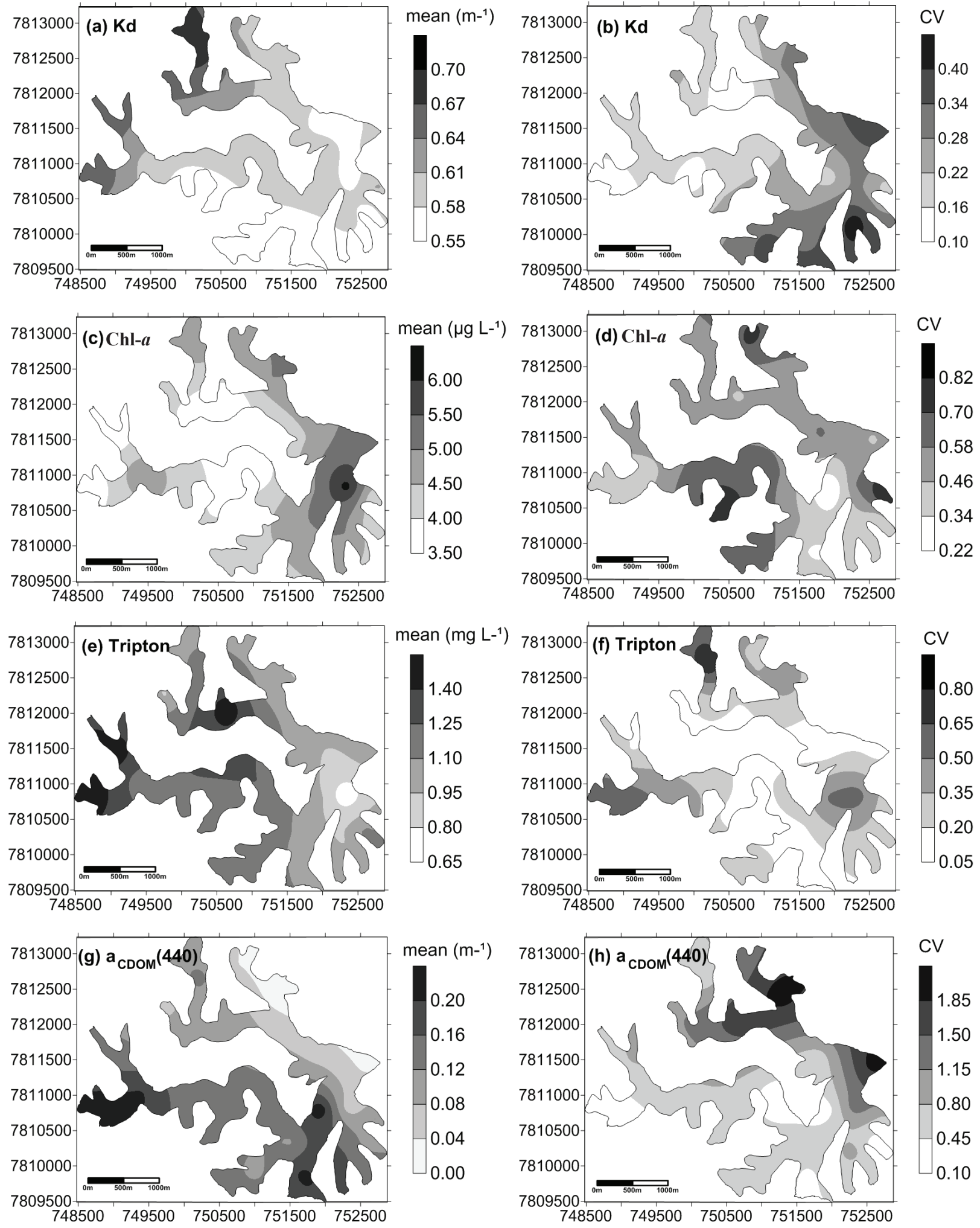

Figure 4 - Mean values (left panel) and coefficients of variation (CV; right panel) of each sampling site during the four seasons for $K d(\mathbf{a}, \mathbf{b}), C h l-a\left(\mu \mathrm{g} \mathrm{L}^{-1}\right)(\mathbf{c}, \mathbf{d})$, tripton $\left(\mathrm{mg} \mathrm{L}^{-1}\right)(\mathbf{e}, \mathbf{f})$ and $\mathrm{a}_{\mathrm{CDOM}}(440)\left(\mathrm{m}^{-1}\right)(\mathbf{g}, \mathbf{h})$. The numbers on the axes correspond to geographic coordinates. 

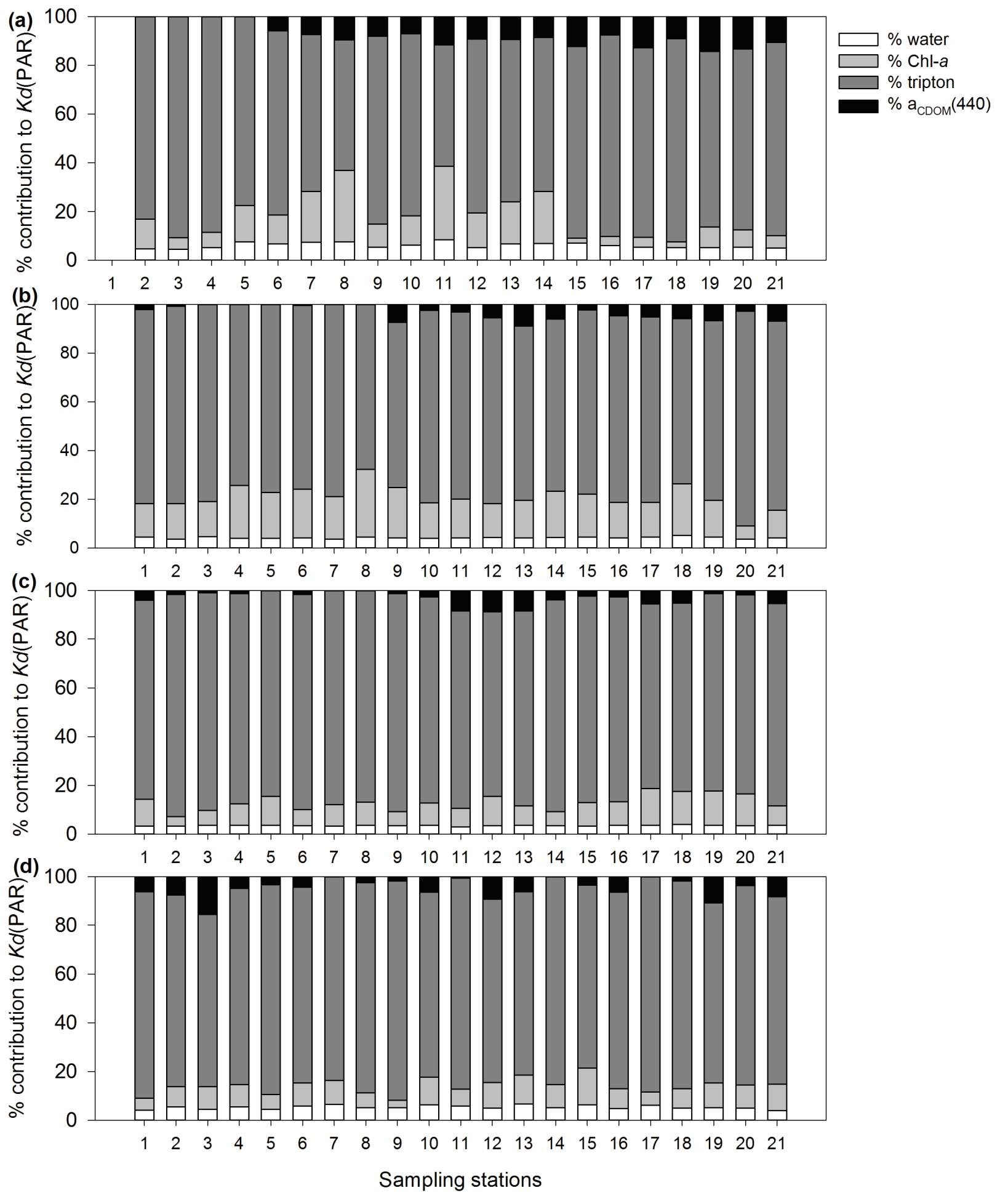

Figure 5 - The contributions of pure water, phytoplankton, tripton and colored dissolved organic matter to $K d(P A R)$ during (a) summer, (b) autumn, (c) winter and (d) spring. 

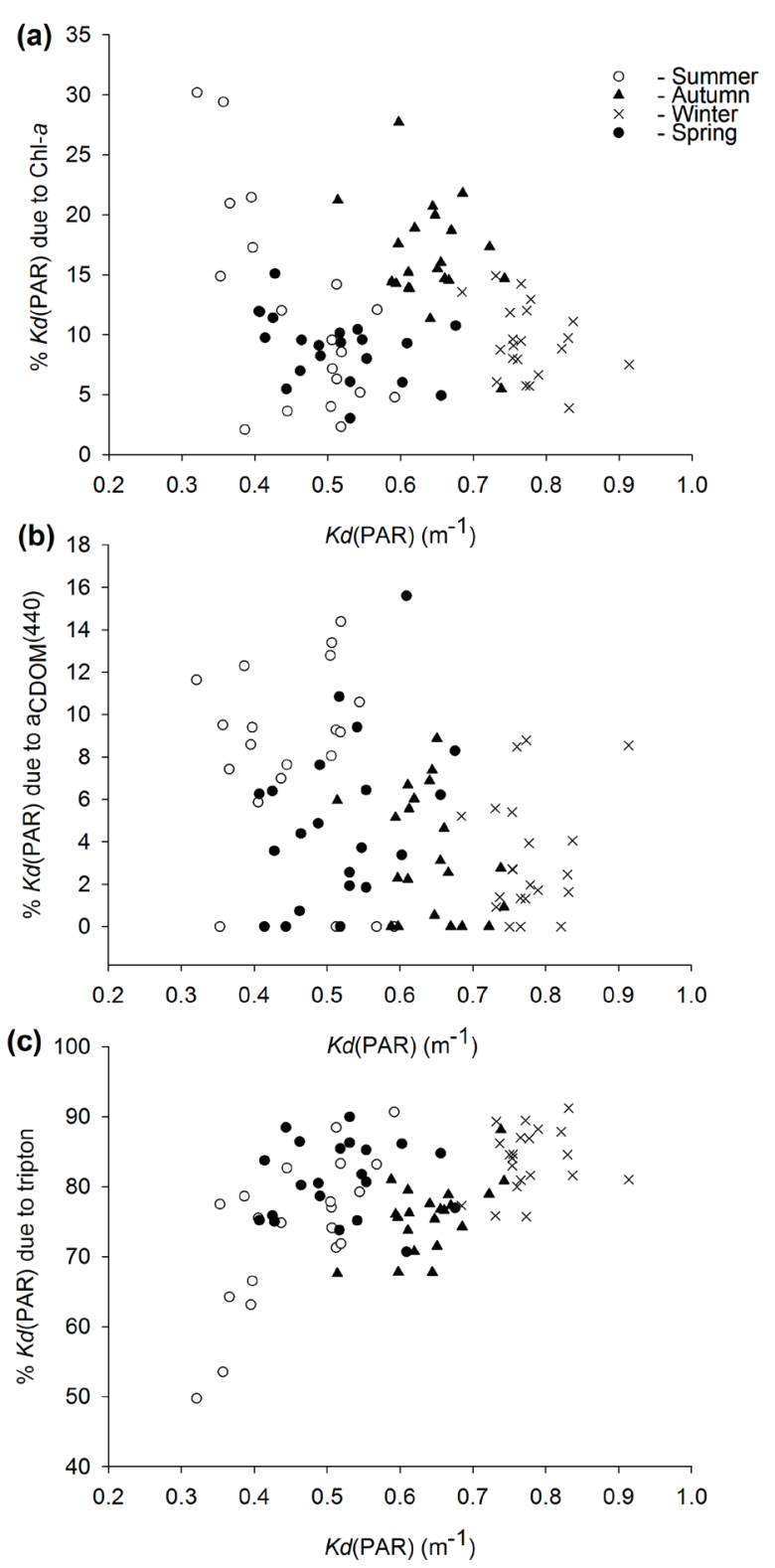

Figure 6 - The relative contributions of Chl- $a$ (a), $\mathrm{a}_{\mathrm{CDOM}}(440)$ (b) and tripton (c) to $K d$ (PAR) during the spatial measurements.

2012) to 0.6 (July 2011) (average $0.3 \mathrm{~m}^{-1}$ ). Overall higher concentration of Chl- $a$, TSM, tripton and $\mathrm{a}_{\text {СDOM }}(440)$ occurred during the dry season of 2011 and 2012. The $\mathrm{a}_{\mathrm{CDOM}}(440)$ absorption ranged from 0.1 (November 2012) to 0.6 (July 2011) (average $0.3 \mathrm{~m}^{-1}$ ). There was a noticeable fall in the concentration of DOC and $\mathrm{a}_{\mathrm{CDOM}}(440)$ from June 2011 to December 2012 (Table I and Fig. 2-e, f, g).
For the monthly and annual variations observed at the station P8 tripton was most predominant in June, July, November and December 2011, and January and December 2012. The contribution of tripton attenuation varied from a minimum of $18.3 \%$ (May 2012) to maximum of $77.2 \%$ (December 2011) and an overall average of $47.8 \%$ throughout the sampling period. In October 2011 and March to August 2012, Chl- $a$ was the primary contributor to $K d$. Throughout the period the Chl- $a$ showed a minimum contribution of $6.8 \%$, maximum of $65.3 \%$ and an average of $35.6 \%$. In June 2012, Chl- $a$ and tripton contributed almost equally with $45.6 \%$ and $45.5 \%$, respectively. We observed that the Chl- $a$ contribution increased in the dry mixing periods. The $\mathrm{a}_{\mathrm{CDOM}}(440)$ contribution to $K d$ ranged between $3.4 \%$ and $22 \%$ with an average of $12 \%$. Pure water contributed with only $4.6 \%$ on average (Table II and Fig. 7).

Using a multiple regression analysis we found that $\mathrm{K}_{\mathrm{Chl}}$ and $\mathrm{K}_{\mathrm{TRIP}}$ together explained $97 \%$ of $K d\left(\mathrm{~F}(2,9)=139.832, \mathrm{p}<0.001, \mathrm{R}=0.98, R^{2}=\right.$ $0.97)$. The regression coefficient for Chl- $a(0.96)$ was higher than for tripton (0.92), which means that while total PAR attenuation depended on a combination of optical conditions, the single most important component driving temporal variation in $K d$ was Chl- $a$ (Fig. 8).

From the analysis of correlations between optical components and physical and chemical conditions characterizing changes at the central station in the lake we found significant correlations $(\mathrm{p}<0.05)$ between: 1$) K d$ and Chl- $a(\mathrm{R}=0.66)$ and rainfall $(\mathrm{R}=-0.58) ; 2) \mathrm{TSM}$ and tripton $(\mathrm{R}=0.92)$, $\mathrm{Z}_{\text {mix }}(\mathrm{R}=0.71)$ and Schmidt Stability $(\mathrm{R}=-0.61)$; 3) Schmidt Stability and $E_{0}(R=0.74)$ and $E_{\text {mean }}(R$ $=0.71)$; 4) $\mathrm{E}_{0}$ and $\mathrm{Z}_{\text {mix }}(\mathrm{R}=0.61)$ and $\mathrm{DOC}(\mathrm{R}=$ $-0.49)$; 5) tripton and $Z_{\text {mix }}(R=0.62)$; 6) $Z_{\text {eu }}$ and rainfall $(\mathrm{R}=0.62) ; 7) \mathrm{a}_{\mathrm{CDOM}}(440)$ and DOC $(\mathrm{R}=$ $0.60)$; and 8) Chl- $a$ and rainfall $(\mathrm{R}=-0.59)$. All correlations of these parameters are shown in Table III. These correlations indicate that the seasonal 
changes in optical components affecting PAR attenuation are strongly linked to meteorological conditions as these affect water column stability and mixing conditions. The combination of these couplings are finally shown as responses in mean light available and the depth of the photic zone.

\section{DISCUSSION}

\section{SPATIAL SAMPLING AT 21 STATIONS}

Considering the coefficients of variation, the optically active components and $K d$ varied among the 21 sampled sites, but these spatial variability were not significant related among them or explained by the sites depth or proximity with the lake shore as expected. Some deep stations ( $>10 \mathrm{~m}$ ) accordingly had variation in $K d$ values similar to stations located near the shore suggesting that other parameters such as complex internal movement of water driven by wind may control the spatial heterogeneity in PAR attenuation (Somlyody and Koncsos 1991). However, although there wasn't relation between the coefficients of variation of $K d$ and the coefficients of variation of the other parameters, we found a significant and positive correlation between $K d$ values and Chl- $a$ concentrations analyzing all sites and sampling periods together. In this way, although tripton had contributed more with the total PAR attenuation in all sites and seasons, the Chl- $a$ concentration was the only parameter correlated with the variation of $K d$.

In addition to the spatial variability among sites, there were distinct spatial variability for Chl- $a$, tripton and $\mathrm{a}_{\mathrm{CDOM}}(440)$ also among sampling periods. During the dry and colder winter mixing period elevated levels of particulate matter (phytoplankton and tripton) caused overall higher PAR attenuation. However, the spatial variability of $K d$ in this period was lower (6\%) than that observed in the summer (18\%) and spring (15\%), although the spatial variability of Chl- $a$ and tripton in winter was $30 \%$ and $45 \%$, respectively. It has previously been demonstrated that mixing of the water column causes resuspension of particulate matter increasing turbidity and tripton concentrations (Blom et al. 1994, James et al. 1997, 2004, Phlips et al. 1995, Zhang et al. 2007b), which consequently would explain the higher values of $K d$ and the highest average contribution of tripton (83.9\%) during the mixed dry season. Higher lake transparency (lower values of $K d$ ) occurred in summer and spring, when concentrations of particulate matter were lower, but the $\mathrm{a}_{\mathrm{CDOM}}(440)$ higher and its contribution in $K d$ became more apparent in the sites (Fig. 5a, d). The higher spatial variability of $K d(15-18 \%)$ was observed in periods of more transparent waters (spring and summer), which coincided with the highest spatial variability of Chl- $a$ during the summer (56\%). Despite the increase in Chl- $a$ and $\mathrm{a}_{\text {СDOM }}(440)$ contribution to $K d$ during summer, tripton was largely responsible for the attenuation of visible light when comparing all sites and sampling periods. Moreover, tripton contribution to the attenuation increased with increasing $K d$ value (see Fig. 6). The relationship between reduced Chl- $a$ and $\mathrm{a}_{\text {СDOM }}(440)$ contributions and increasing tripton contribution with the increase of $K d$ was also demonstrated by Zhang et al. (2007a). Other studies have similarly found a strong positive relationship between tripton and $K d$ and a great contribution of this component to PAR attenuation in lakes (Phlips et al. 1995, Christian and Sheng 2003, Yang et al. 2005, Zhang et al. 2007a, Balogh et al. 2009) and estuaries and oceans (McMahon et al. 1992, Lin et al. 2009, Yamaguchi et al. 2013) (See Table IV). In this way, the main component responsible for the PAR attenuation was tripton, followed by Chl- $a$, which is in agreement with our first hypothesis since most of the variability in $K d$ was due to the particulate matter.

The low contribution of $\mathrm{a}_{\text {CDOM }}(440)$ to $K d$ (maximum 15.6\%) was expected since the $\mathrm{a}_{\mathrm{CDOM}}(440)$ occurred at low concentrations in this 

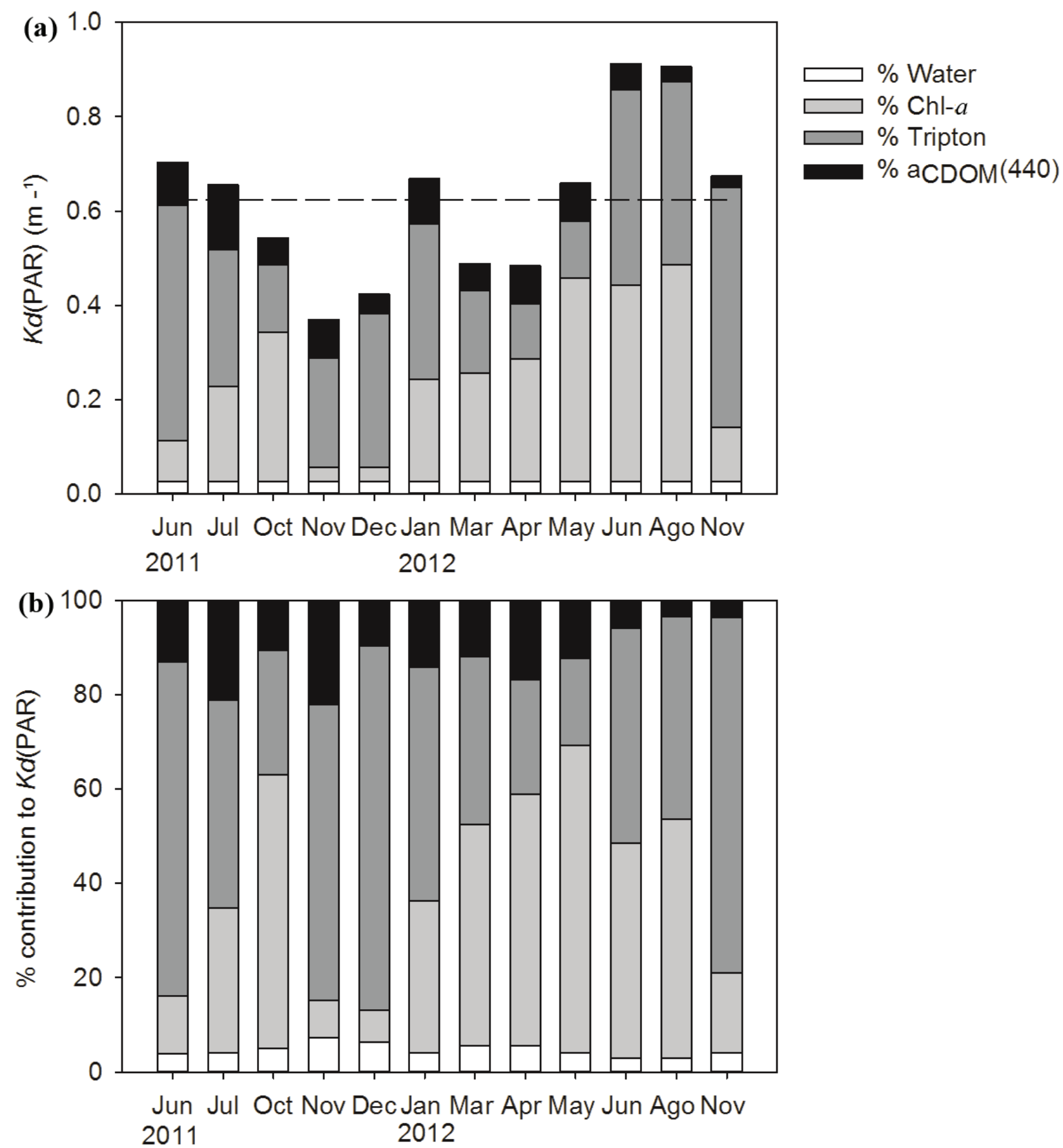

Figure 7 - (a) Temporal variation of the PAR attenuation coefficient in the water column. White, light grey, dark grey and black bars show the partial attenuation coefficients due to pure water $\left(\mathrm{K}_{\mathrm{w}}\right)$, phytoplankton $\left(\mathrm{K}_{\mathrm{Chl}-a}\right)$, tripton $\left(\mathrm{K}_{\text {trip }}\right)$ and $\mathrm{a}_{\mathrm{CDOM}}(440)\left(\mathrm{K}_{\mathrm{CDOM}}\right)$, respectively. The dashed line indicates the average of $K d_{P A R}$ through the study period $\left(0.62 \mathrm{~m}^{-1}\right)$. (b) Percentage contributions of the $\mathrm{K}_{\mathrm{w}}, \mathrm{K}_{\text {chla }}, \mathrm{K}_{\text {trip }}$ and $\mathrm{K}_{\mathrm{CDOM}}$ to $K d(\mathrm{PAR})$ during the same period. 
TABLE III

Pearson correlations of the parameters obtained in the analysis of temporal changes at central station in 2011 and 2012. Significant correlations are highlighted in bold. $(\mathrm{St}=\mathrm{Schmidt}$ stability; $\mathbf{E 0}=$ irradiance; $\mathrm{Z}=$ euphotic zone depth).

\begin{tabular}{|c|c|c|c|c|c|c|c|c|c|c|c|}
\hline & TSM & $\begin{array}{c}\text { Chl- } a \\
\left(\mu \mathrm{g} \mathrm{L}^{-1}\right)\end{array}$ & Tripton & $\begin{array}{l}a_{\text {CDOM }} \\
(440) \\
\left(m^{-1}\right)\end{array}$ & St & $\begin{array}{c}\text { E0 } \\
\text { (mol } \\
\text { photons } \\
\mathrm{m}^{-2} \mathrm{~d}^{-1} \text { ) }\end{array}$ & $\begin{array}{c}\text { Emean } \\
\text { (mol } \\
\text { photons } \\
\left.\mathrm{m}^{-2} \mathrm{~d}^{-1}\right)\end{array}$ & Zeu & Zmix & $\begin{array}{l}\text { DOC } \\
\text { (mg } \\
\left.\text { L-1) }^{-1}\right)\end{array}$ & Rainfall \\
\hline $\begin{array}{l}k d(\mathbf{P A R}) \\
\left(\mathrm{m}^{-1}\right)\end{array}$ & 0.56 & $* 0.66$ & 0.24 & -0.14 & -0.48 & -0.32 & $* *_{-} \mathbf{0 . 8 1}$ & $* * * \mathbf{0} .82$ & 0.41 & -0.24 & $*-0.57$ \\
\hline TSM & & -0.07 & $* * * 0.92$ & 0.15 & ${ }^{*}-0.61$ & -0.41 & $*-0.69$ & -0.52 & $* * 0.70$ & 0.41 & -0.12 \\
\hline Chl- $a$ & & & -0.45 & -0.13 & -0.17 & -0.12 & -0.41 & -0.49 & 0.02 & -0.45 & $*_{-0.58}$ \\
\hline Tripton & & & & 0.19 & -0.48 & -0.32 & -0.46 & -0.28 & $* 0.62$ & 0.54 & 0.12 \\
\hline $\begin{array}{l}a_{\text {СDOM }} \\
(\mathbf{4 4 0 )}\end{array}$ & & & & & -0.30 & -0.49 & -0.20 & 0.10 & 0.49 & $* 0.60$ & -0.09 \\
\hline St & & & & & & $* * * 0.73$ & $* * * 0.71$ & 0.40 & $* * *-0.71$ & -0.33 & 0.12 \\
\hline E0 & & & & & & & $* * * 0.82$ & 0.39 & $* *-0.61$ & $*_{-} 0.49$ & 0.11 \\
\hline Emean & & & & & & & & $* * * 0.71$ & $* * *-0.78$ & -0.25 & 0.37 \\
\hline Zeu & & & & & & & & & -0.39 & 0.14 & $* * 0.62$ \\
\hline
\end{tabular}

$* \mathrm{p}<0.05, * * \mathrm{p}<0.01, * * * \mathrm{p}<0.001$.

lake and its absorption decays with increasing wavelength (Green and Blough 1994, Kitidis et al. 2006), implying that the overall contribution of $\mathrm{a}_{\text {CDOM }}(440)$ absorption is higher in the ultraviolet part of the spectra $(200-400 \mathrm{~nm})$.

\section{MONTHLY SAMPLING AT THE DEEP CENTRAL STATION}

In the monthly sampling at the deep central station 8 (between 2011 and 2012), the contribution of Chl- $a$ for the total lightattenuation was more noticeable and higher than the tripton contribution in some periods (October-2011 and from March to August-2012). The majority of studies, predominantly in coastal waters, showed that the relative contribution of tripton to the PAR attenuation was always higher than that of Chl- $a$. This has been documented in Aarhus Bay, Kattegat (Lund-Hansen 2004), Florida Bay (Phlips et al. 1995, Kelble et al. 2005), Tampa Bay and Charlotte Harbor (McPherson and Miller 1987, McPherson and Miller 1994) and in the Yellow Sea (Lin et al. 2009). While tripton is often dominate light attenuation, Zhang et al. (2007b) showed that increases in Chl- $a$ during summer algal blooms makes light absorption by pigments a more dominant optical component than tripton in some regions of Taihu Lake (China). In hypereutrophic lakes Balogh et al. (2009) also observed higher Chl- $a$ contribution to the PAR attenuation and Yang et al. (2005) in some regions of the Lake Donghu (China). Effler et al. (2010) in contrast, found that $\mathrm{a}_{\mathrm{CDOM}}(440)$ was the primarily factor responsible for PAR attenuation in Lake Superior (USA). In our study, Chl- $a$ and tripton together explained $97 \%\left(R^{2}\right.$, multiple linear regression) of the temporal variation of $K d$ but the Chl- $a$ was the most responsible. Similar results were found by Yamaguchi et al. (2013) where although tripton have been the predominant component responsible for the $K d$ in percentage of attenuation, Chl- $a$ was the main component that influenced the $K d$ monthly variation in Harima Sound $\left(\mathrm{R}^{2}=75 \%\right)$ (Eastern Seto Inland Sea, Japan). Obrador and Pretus (2008) also demonstrated that the main driver for seasonal 


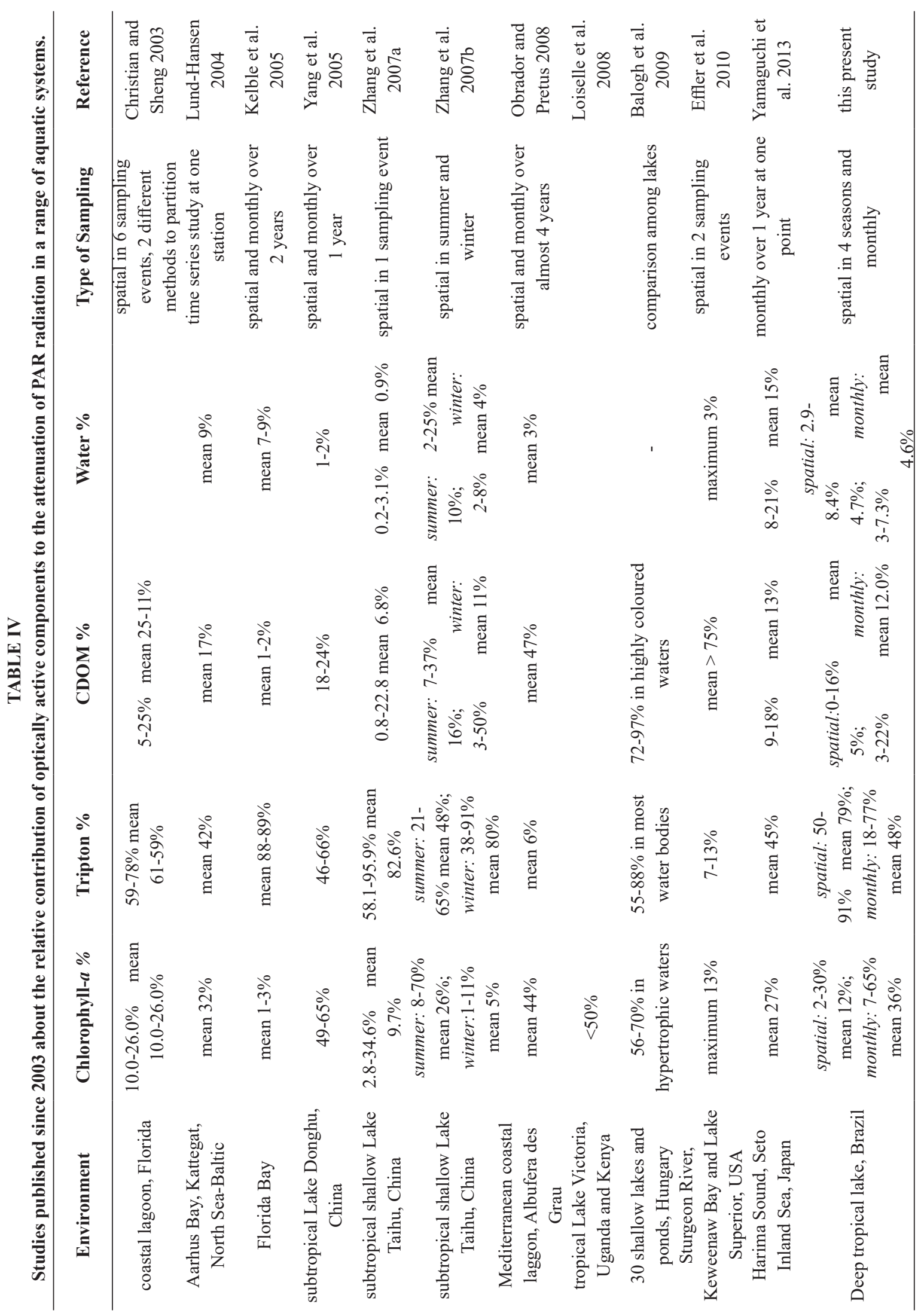




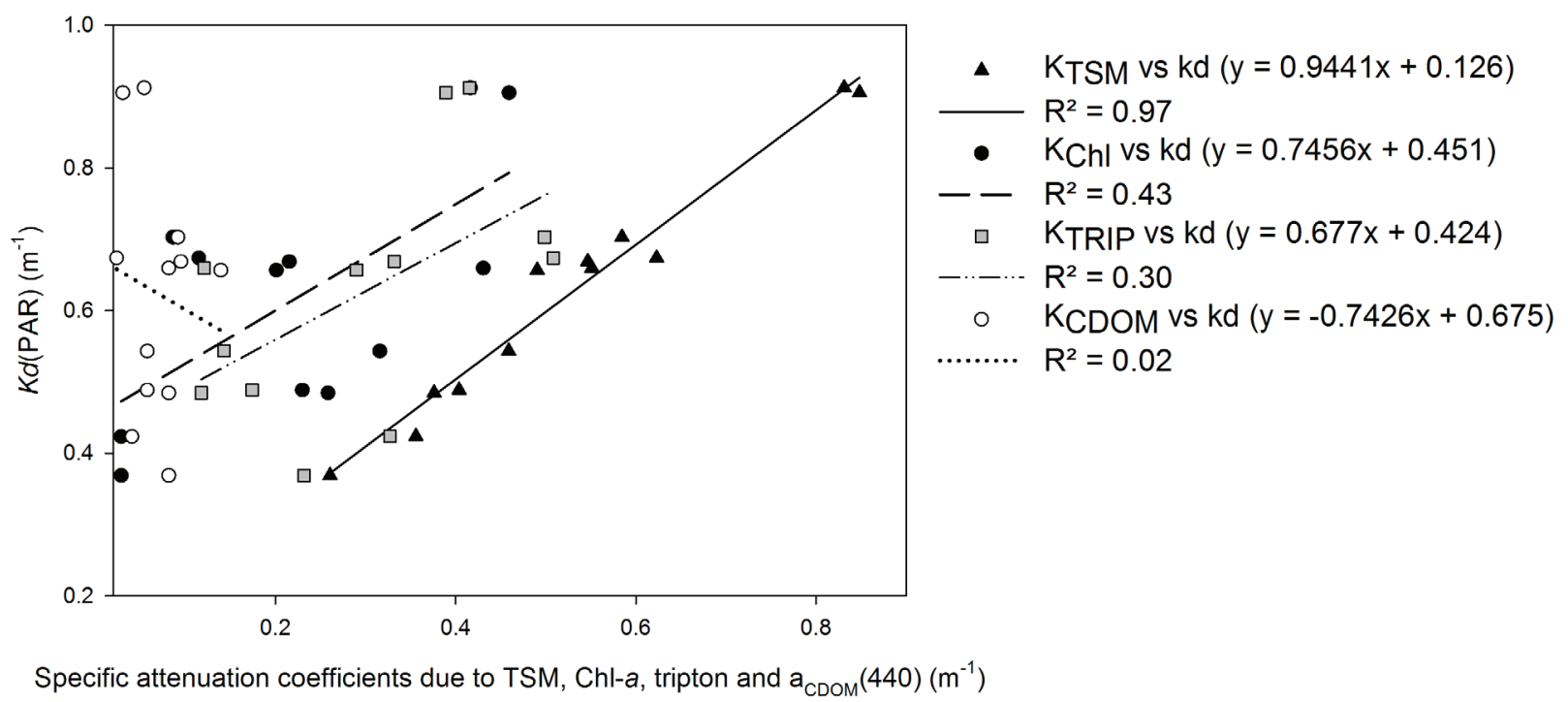

Figure 8 - Simple linear regressions between $K d(\mathrm{PAR})$ and partial attenuation coefficients of visible radiation due to TSM (triangles), tripton (crosses), Chl- $a$ (black circles) and $\mathrm{a}_{\mathrm{CDOM}}(440)$ (white circles) during monthly sampling.

changes in $K d$ was phytoplankton (Chl-a) despite that DOC had a higher relative contribution. Reinforcing this conclusion, we found a smaller temporal variation in tripton concentration (coefficient of variation: $\mathrm{CV}=0.51$.) than in Chl- $a$ $(\mathrm{CV}=0.65)$, which suggests that although tripton contributed significantly to light attenuation, variations in Chl- $a$ was the main driver for seasonal fluctuations in $K d$ values. This finding allows us to conclude that the main factor that attenuates light is not necessarily the same one that causes temporal variation of the light attenuation (Obrador and Pretus 2008) (see Table IV).

From our monthly sampling we found that higher irradiance and rainfall values in summer were positively related to the mean light available to primary production $\left(\mathrm{E}_{\text {mean }}\right)$ and Schmidt stability while negatively related to the mixed layer depth $\left(Z_{\text {mix }}\right)$. In this period, the DOC and $\mathrm{a}_{\text {CDOM }}(440)$ occurred in low concentrations in the photic zone suggesting high photobleaching caused by the high incident radiation. It is known that with rain allochthonous carbon enters the deeper layers of the lake and remains in the hypolimnion until mixing period, when it becomes distributed in the water column (Reynolds 2009). Corroborating this finding we observed higher DOC concentration at the bottom of the lake than at the subsurface in the rainy period (November and December 2012). With a lower incidence of solar radiation and cooling of surface waters during winter the depth of the mixed layer increased, causing a more homogeneous distribution of nutrients and particulate matter in the water column (Barbosa and Tundisi 1980, Petrucio and Barbosa 2004, Brighenti et al. 2015). This would explain the observed increase in Chl- $a$ concentrations in the full mixing period in 2012 and its higher relative contribution in PAR attenuation (maximum 65\% in May 2012). Brighenti et al. (2015) investigating the patterns of primary production in Dom Helvécio lake during 2011 to 2012 demonstrated that during thermally stratified period, with higher surface light and lower light attenuation, coincided with a higher occurrence of photoinhibition of phytoplankton productivity. Also these authors found that the availability of nutrients and the highest phytoplankton biomass coincided with periods of lower photoinhibition (mixing 
periods). Thus, the increase of Chl- $a$ combined with the increase of tripton concentrations in mixing period resulted in higher values of $K d$ at this time.

\section{CONCLUSIONS}

The present study demonstrated that is important to link temporal and spatial sampling in order to understand the role of the optical components influencing PAR attenuation, because the main component that attenuates light is not necessarily the same component responsible for the temporal variation of $K d$. Optimally this should be combined with a high-frequency sampling of physical conditions characterizing water column mixing conditions. This combination allows better certainty of the importance of each optical component for the total attenuation of light and a better mechanistic understanding of the physical and chemical conditions driving temporal changes. Particularly, we found that there was a significant temporal and spatial variability in water transparency, and although most of PAR attenuation occured due to tripton concentrations, the variability of $K d$ was mainly associated to variation in the concentration of Chl- $a$. However, we did not find support for our expectation of higher variability in optical condition at near shore sites, suggesting that new studies on the variability in $K d$ must consider the hydrodynamic conditions in the distribution of optical components within the lake.

\section{ACKNOWLEDGMENTS}

We thank the laboratories LIMNEA and LGAR (UFMG, Minas Gerais, Brazil) for their infrastructure and to Marcelo Costa and Patrícia Ferreira for the chemical analysis and all help in this project. We also thank the Conselho Nacional de Desenvolvimento Científico e Tecnológico (CNPq/ 478901/2013-5), the Brazil-LTER/PELD/CNPq, the Coordenação de Aperfeiçoamento de Pessoal de Nível Superior (CAPES) and the project Carbon
Cycling in Lakes (COCLAKE - CAPES Proc. $n^{\circ}$ 88881.030499/2013-01) for financial support. LSB was supported by Capes.

\section{REFERENCES}

APHA. 1998. Standard Methods for the Examination of Water and Wastewater, APHA, Washington, DC.

BALOGH KV, NÉMETH B AND VOROS L. 2009. Specific attenuation coefficients of optically active substances and their contribution to the underwater ultraviolet and visible light climate in shallow lakes and ponds. Hydrobiologia 632: 91-105.

BARBOSA FAR AND TUNDISI JG. 1980. Primary production of phytoplankton and environmental characteristics of a shallow quaternary lake at Eastern Brazil. Arch Hydrobiol 90: 139-161.

BEZERRA-NETO JF AND PINTO-COELHO RM. 2008. Morphometric study of Lake Dom Helvécio, Parque Estadual do Rio Doce (PERD), Minas Gerais, Brazil: a reevaluation. Acta Limnol Bras 20(2): 161-167.

BLOM G, VAN DUIN EHS AND LIJKLEMA L. 1994. Sediment resuspension and light conditions in some shallow Dutch lakes. Water Sci Technol 30: 243-252.

BRANCO AB AND KREMER JN. 2005. The relative importance of $\mathrm{Chl}$ and colored dissolved organic matter (CDOM) to the prediction of the diffusive attenuation coefficient in shallow estuaries. Estuaries 28: 643-652.

BRIGHENTI LS, STAEHR PA, GAGLIARDI LM, BRANDÃO LPM, ELIAS EC, MELLO NAST, BARBOSA FAR AND BEZERRA-NETO JF. 2015. Seasonal changes in metabolic rates of two tropical lakes in the Atlantic forest of Brazil. Ecosystems 18: 589-604.

CHRISTIAN D AND SHENG YP. 2003. Relative influence of various water quality parameters on light attenuation in Indian River Lagoon. Estuar Coast Shelf S 57: 961-971.

EFFLER SW, PERKINS ML, PENG F, STRAIT C, WEIDEMANN AD AND AUER MT. 2010. Lightabsorbing components in Lake Superior. J Great Lakes Res 36: 656-665.

GALLEGOS CL AND MOORE K. 2000. Factors contributing to water-column light attenuation. In: Batiuk RA et al. (Eds), Chesapeake Bay Submerged Aquatic Vegetation Water Quality and Habitat-based Requirements and Restoration Targets: A Second Technical Synthesis. US Environmental Protection Agency, Annapolis, p. 35-54.

GREEN SAAND BLOUGH NV. 1994. Optical absorption and fluorescence properties of chromophoric dissolved organic matter in natural waters. Limnol Oceanogr 39: 1903-1916.

JAMES R, MARTI TJ, WOOL T AND WANG PF. 1997. A sediment resuspension and water quality model of Lake Okeechobee. J Amer Wat Resour Assoc 33: 661-680. 
JAMES WF, BEST EP AND BARKO JW. 2004. Sediment resuspension and light attenuation in Peoria Lake: can macrophyte improve water quality in this shallow system? Hydrobiologia 515: 193-201.

KELBLE CR, ORTNER PB, HITCHCOCK GL AND BOYER JN. 2005. Attenuation of photosynthetically available radiation (PAR) in Florida Bay: potential for light limitation of primary producers. Estuaries 28: 560-571.

KIRK JTO. 1994. Light and photosynthesis in aquatic ecosystem. Cambridge University Press, Cambridge, p. $1-431$.

KITIDIS V, STUBBINS AP, UHER G, UPSTILL GODDARD RC, LAW CS AND WOODWARD EMS. 2006. Variability of chromophoric organic matter in surface waters of the Atlantic Ocean. Deep Sea Res 53: 1666-1684.

LIN S, ZOU T, GAO H AND GUO X. 2009. The vertical attenuation of irradiance as a function of turbidity: a case of Huanghai (Yellow) Sea in spring. Acta Oceanol Sin 28: 66-75.

LOISELLE SA, AZZA N, COZAR A, BRACCHINI L, TOGNAZZI A, DATTILO AM AND ROSSI C. 2008. Variability in factors causing light attenuation in Lake Victoria. Freshw Biol 53: 535-545.

LUND-HANSEN LC. 2004. Diffuse attenuation coefficients $K d(\mathrm{PAR})$ at the estuarine North Sea-Baltic Sea transition: time-series, partitioning, absorption, and scattering. Estuar Coast Shelf Sci 61: 251-259.

MACKERETH FJH, HERON J AND TALLING JF. 1978. Water analysis and some revised methods for limnologists. Freshwater Biological Association Scientific Publication $36,117 \mathrm{p}$.

MAIA-BARBOSA PM, BARBOSA LG, BRITO SL, GARCIA F, BARROS CF, SOUZA MB, MELLO N, GUIMARÃES AS AND BARBOSA FA. 2010. Limnological changes in Dom Helvécio Lake (South-East Brazil): natural and anthropogenic causes. Braz J Biol 70(3 Suppl): 795-802.

MCMAHON TG, RAINE RCT, FAST T, KIES L AND PATCHING JW. 1992. Phytoplankton biomass, light attenuation and mixing in the Shannon estuary, Ireland. J Mar Biol Assoc UK 72: 709-720.

MCPHERSON BF AND MILLER RL. 1987. The vertical attenuation of light in Charlotte Harbor, a shallow, subtropical estuary, south-western Florida. Estuar Coast Shelf Sci 25: 721-737.

MCPHERSON BF AND MILLER RL. 1994. Causes of light attenuation in Tampa Bay and Charlotte Harbor, Southwestern Florida. Water Resour Bull 30(1): 43-53.

OBRADOR B AND PRETUS JL. 2008. Light regime and components of turbidity in a Mediterranean coastal lagoon. Estuar Coast Shelf Sci 77: 123-133.

PARSONS TR, TAKAHASHI M AND HARGRAVE B. 1984. Biological Oceanographic Processes. 3rd ed., Pergamon Press, Oxford.
PETRUCIO MM AND BARBOSA FAR. 2004. Diel variations of phytoplankton and bacterioplankton production rates in four tropical lakes in the middle Rio Doce basin (southeastern Brazil). Hydrobiologia 513: 71-76.

PFANNKUCHE J. 2002. Optical properties of Otago shelf waters: South Island New Zealand. Estuar Coast Shelf Sci 55: 613-627.

PHLIPS EJ, LYNCH TC AND BADYLAK S. 1995. Chl- $a$, tripton, color, and light availability in a shallow tropical inner-shelf lagoon. Florida Bay, USA. Mar Ecol Prog Ser 127: 223-234.

PIERSON DC, MARKENSTEN H AND STRÖMBECK N. 2003. Long and short term variations in suspended particulate material: the influence on light available to the phytoplankton community. Hydrobiologia 494: 299-304.

READ JS, HAMILTON DP, JONES ID, MURAOKA K, WINSLOW LA, KROISS R, WU CH AND GAISER E. 2011. Derivation of lake mixing and stratification indices from high-resolution lake buoy data. Environ Model Softw 26: $1325-1336$.

REYNOLDS CS. 2009. Hydrodynamics and mixing in lakes, reservoirs, wetlands and rivers in Biogeochemistry of inland waters: a derivative of encyclopedia of inland waters. Editor Gene E. Likens, Cary Institute of Ecosystem Studies Millbrook, NY, USA, p. 189-196.

SMITH RC AND BAKER KS. 1978. The bio-optical state of ocean waters and remote sensing. Limnol Oceanogr 23: 247-259.

SOMLYODY L AND KONCSOS L. 1991. Influence of sediment resuspension on the light conditions and algal growth in Lake Balaton. Ecol Model 57: 173-192.

STAEHR PA AND SAND-JENSEN K. 2007. Temporal dynamics and regulation of lake metabolism. Limnol Oceanogr 52: 108-120.

VAN DUIN EHS, BLOM G, LOS FJ, MAFFIONE R, ZIMMERMAN R, CERCO CF, DORTCH MS AND BEST EPH. 2001. Modeling underwater light climate in relation to sedimentation, resuspension, water quality and autotrophic growth. Hydrobiologia 444: 25-42.

WILLIAMSON CE, STEMBERGER RS, MORRIS DP, FROST TM AND PAULSEN SG. 1996. Ultraviolet radiation in North American lakes: attenuation estimates from DOC measurements and implications for plankton communities. Limnol Oceanogr 41: 1024-1034.

YAMAGUCHI H, KATAHIRA R, ICHIMI K AND TADA K. 2013. Optically active components and light attenuation in an offshore station of Harima Sound, eastern Seto Inland Sea, Japan. Hydrobiologia 714: 49-59.

YANG HONG, PING XIE, YANGPING XING, LEYI NI AND HONGTAO GUO. 2005. Attenuation of Photosynthetically Available Radiation by Chlorophyll, Chromophoric Dissolved Organic Matter, and Tripton in Lake Donghu, China. J Fresh Ecol 20(3): 575-581. 
ZHANG Y, ZHANG B, MA R, FENG S AND LE C. 2007a. Optically active substances and their contributions to the underwater light climate in Lake Taihu, a large shallow lake in China. Fundam Appl Limnol 170: 11-19.
ZHANG Y, ZHANG B, WANG X, LI J, FENG S, ZHAO Q, LIU M AND QIN B. 2007b. A study of absorption characteristics of chromophoric dissolved organic matter and particles in Lake Taihu, China. Hydrobiologia 592: 105-120. 